\title{
The Gases of War
}

\author{
By Arthur Marshall
}

$\mathrm{T}^{\mathrm{H}}$ HE word 'gas' has come to stay as the name of the atmospheric poisons that are used in warfare, but it is an unfortunate one as most of them are liquids and not very volatile, and some are non-volatile solids that are used in the form of aerosols. It is generally assumed that if air raids are perpetrated in a future war, the bombs will mostly be charged with 'gas', but this is by no means certain. High explosive bombs would not only destroy more property, but would also probably inflict far more casualties than chemical bombs. On the other hand, bombing or spraying with a persistent substance, such as mustard gas, would greatly disorganise the life of a big city, as it would force the majority of the population to keep indoors until the contamination had been cleared away by the special squads. It is likely, then, that the raiders would use a mixture of high explosive, gas and incendiary bombs, and of course the raids would be on a vastly bigger scale than in 1917-18, because the aeroplanes available would be far larger and more numerous.

Atmospheric poisons can be classified in various ways, according to their persistence (depending principally on their vapour pressure), or according to their chemical composition, or their physiological action or their use in warfare. The last two ways lead to much the same result, and form the basis of the classification that is generally adopted. There are four main classes, which have been given various names.

\section{Class A. Choking Gases (Lethal)}

French: Suffocants. German: Green Cross or Lungenreizstoffe.

Chlorine, $\mathrm{Cl}_{2}$, the first substance to be used effectively (in April 1915) belongs to this class. It was discharged from cylinders in the form of a cloud. Its characteristics are sufficiently well known.

Phosgene, $\mathrm{COCl}_{2}$, replaced chlorine to a large extent, but as it liquefies under atmospheric pressure at $8 \cdot 2^{\circ}$, it was necessary to mix chlorine with it in the cylinders. It was used in this way right up to the end of the War, especially by the British ; alone or mixed with other poisons, it formed the charge of shells and large bombs thrown by projectors. In the British service it was called CG, from the French 'collongite'. It is much more toxic than chlorine, and has a delayed action, which renders it especially dangerous; it affects the eyes to some extent as well as the throat.
Trichloromethylchloroformate, $\mathrm{CClO} . \mathrm{CCl}_{3}$, is very similar in its action to phosgene, but has a boiling point of $127^{\circ}$ and consequently has a certain amount of persistence. It was used largely by the Germans in their shells and was called by them 'Perstoff', whereas the British named it 'diphosgene' and the French 'surpalite'.

\section{Class B. Nose Gases or Sternutators}

French: Irritants respiratoirs. German: Blue Cross or Hustenreizstoffe.

These substances were used on a large scale by the Germans during the last year of the War. They are all solid arsenical compounds practically nonvolatile at the ordinary temperature. The Germans fired them in shells charged also with high ex. plosive, which reduced them to a very fine state of division so that they should penetrate the gas masks. By causing the wearer to cough and sneeze violently and vomit, they forced him to remove the mask and expose himself to some other more toxic gas. Other symptoms produced are running at the eyes, pains in the gums, intense headache and general depression; but the sufferer makes a complete recovery in a comparatively short time. According to General Foulkes ("Gas, the Story of the Special Brigade", Blackwood, 1934, pp. 249 et seq.), they were not very effective as used by the Germans, since the particles were not suffi. ciently minute to penetrate our gas masks; but it was found in the British service that they pro. duced far more powerful effects if released as a smoke by vapourising them in a special form of thermo-generator or 'candle'. At the time of the Armistice, active preparations were being mado to supply these in large quantities, and thereby it was hoped to obtain a decided military effect.

Diphenylarsine chloride, $\left(\mathrm{C}_{6} \mathrm{H}_{5}\right)_{2} \mathrm{AsCl}$, was the first of these substances to be used (July 1917). The Germans called it 'Clark I' and the British 'DA'.

Diphenylarsine cyanide, $\left(\mathrm{C}_{6} \mathrm{H}_{5}\right)_{2} \mathrm{AsCN}$, is even more violent in its action, and for this reason was introduced by the Germans in May 1918. The German name is 'Clark II' and the English 'DC'.

Diphenylaminearsine chloride, $\mathrm{NH}\left(\mathrm{C}_{6} \mathrm{H}_{6}\right)_{2} \mathrm{AsCl}$, unlike the atmospheric poisons already mentioned, had not been prepared before the War. It is said to have been discovered by Wieland in Germany in 1915, and by Adams in the United States in January 1918. This was the substance which the 
Allies were to have used in the thermo-generators, but it was never actually tried at the front. It is called 'adamsite' or 'DM', and is reputed to be even more potent than ' $\mathrm{DC}$ '.

\section{Class C. Tear Gases or Lachrymators}

French: Lachrymogènes. German: White Cross or Augenreizstoffe.

These were used extensively in the earlier stages of the War, but did not cause many serious casualties; they make the eyes run and consequently compel the wearing of gas masks and so reduce the military value of the enemy. In future wars they are likely to be replaced to a considerable extent by nose gases. Tear gas bombs have been used in America and other countries for dispersing riots, because they incapacitate the roters without inflicting permanent injury on them.

Benzyl bromide, $\mathrm{C}_{6} \mathrm{H}_{5} . \mathrm{CH}_{2} \mathrm{Br}$, and xylyl bromide, $\mathrm{CH}_{3} \cdot \mathrm{C}_{6} \mathrm{H}_{4} \cdot \mathrm{CH}_{2} \mathrm{Br}$, were among the first poisons used for charging shells, but were afterwards replaced by more pungent lachrymators. The Germans called them 'T-Stoff'; the French referred to benzyl bromide as 'cyclite'.

Bromoacetone, $\mathrm{CH}_{3} . \mathrm{CO} . \mathrm{CH}_{2} \mathrm{Br}$, has a considerably stronger action and was introduced by the Germans in July 1915 as a filling for shells and hand-grenades under the name of 'B-Stoff'. The French call it 'martonite'. It is less persistent than the above, as it boils at $135^{\circ}$, whereas benzyl and xylyl bromides boil at $198^{\circ}$ and $215^{\circ}$. It does not keep well.

Chloropicrin, $\mathrm{CCl}_{3} \mathrm{NO}_{2}$, is still more volatile (b.p. $26.5^{\circ}$ ), and was sometimes mixed with chlorine in cloud attacks, and with phosgene in projector and trench mortar bombs. It affected not only the eyes, but also caused coughing, romiting and even death, so that it forced the enemy to remove his gas mask. In the British service it was called 'PS'; the French name is 'aquinite' and the German 'Klop'.

Chloroacetophenone, $\mathrm{C}_{6} \mathrm{H}_{5} \cdot \mathrm{CO} \cdot \mathrm{CH}_{2} \mathrm{Cl}$, is an effective lachrymator which might have been used on a considerable scale if the War had lasted longer. It is a solid of low volatility which can be distilled unchanged (b.p. $246^{\circ}$ ), and consequently can be dispersed as an aerosol by means of a thermogenerator (see Héderer and Istin, "L'Arme chimique et ses Blessures", 1935, p. 140).

\section{Class D. Blister Gases or Vesicants}

French: Vésicants. German: Yellow Cross or Hautreizstoffe.

These substances attack the skin even in the form of vapour, but much more when the liquid comes in contact with it, raising blisters which are slow to heal and are liable to lead to secondary infection. They also attack the eyes and lungs, and in severe cases affect the digestion and nerves and in fact upset the whole system.

Dichlorodiethyl sulphide, $\mathrm{S}\left(\mathrm{C}_{2} \mathrm{H}_{4} \mathrm{Cl}\right)_{3}$, or mustard gas (French, 'yperite'; German, 'Lost'), has been known since 1822. It was one of the substances which was examined in the laboratories of the Allies soon after the Germans introduced gas warfare, but its high military value was not perceived until the Germans commenced to use it at the front in July 1917. It was then recognised at once, and attempts were made to work out a method of manufacture. This was found to be far from easy, and no mustard gas of British or American manufacture was actually fired in the War. The French were more successful, and in the last months before the Armistice their 'yperite' was used both by them and the British, causing severe casualties to the enemy.

Full protection against mustard gas requires not only a gas mask but also a complete suit of special clothing. As the vapour has no pronounced smell and produces no immediate effect, it is liable to escape detection until it has had time to cause serious injuries which only develop some hours later. In a future war, it might be used not only as a filling for aerial bombs but also as a spray from aeroplanes.

Chlorovinylarsine dichloride, $\mathrm{ClCH}: \mathrm{CH} \cdot \mathrm{AsCl}_{2}$, known as lewisite, was first made by Lewis in 1904. The Americans, English and Germans were all investigating its possibilities as a poison gas at the time of the Armistice, and the Americans were preparing to manufacture it on a large scale. As it was not actually used, its military value can only be estimated. It has been called the 'dew of death', and most exaggerated claims have been made as to its power of killing off the whole population of a city; but the British chemists who examined it came to the conclusion that it is less dangerous than mustard gas. Others who have made a careful study of the matter consider, however, that lewisite is slightly the more effective. It acts more quickly than mustard gas, but the lesions also heal in a shorter time; it is more volatile and consequently less persistent (b.p. $190^{\circ}$ as compared with $217 \cdot 5^{\circ}$ ). It has a more pronounced smell, and therefore is more easily guarded against.

These are the principal substances which were used in 1915-18, or were about to be used on a considerable scale in 1919. Since then, the 'chemical defence' departments in the various countries have been searching for worse poisons; their results have been kept secret, but there is no evidence that they have been successful. They are heavily handicapped by the want of any reliable method 
of testing their gases in peace time; experiments on animals are liable to be fallacious, as different species vary greatly in their susceptibility to poisons, as indeed do different individuals of the same species. Moreover, when used in large quantities over extensive areas, the effects are often quite different from those obtained in small-scale experiments on a few individuals. Some indication of these difficulties may be gathered from what has been said about mustard gas and lewisite.

It is important to emphasise that practically all these substances were known before the War and were discovered in the course of purely scientific researches conducted without anticipation of the possible uses of the results in warfare. Chlorine is, of course, one of the commonest reagents of the laboratory and works, and was first made by Scheele in 1774. Phosgene was discovered by Davy in 1812. Benzyl bromide, chloropicrin and ' $\mathrm{DA}$ ' can be obtained from the dealers in chemicals, and 'DC' can be made from 'DA' by a simple inter. change. Diphosgene was discovered so long ago as 1847 , and mustard gas in 1822, and bromoacetone in 1863. Although it was not actually used in the War, chloroacetophenone had been discovered by Graebe in 1871, and even lewisite, although it was the result of investigations carried out specially during the War, was discovered in researches started in America in 1904 for purely scientific purposes.

\section{A Recent Discovery in Sixteenth Century Botany}

\section{By Dr. Agnes Arber}

$\mathrm{W}$ HEN, a few years ago, Prof. Walther Rytz of the University of Bern was reviewing the collections in the Botanical Institute, he brought to light a herbarium in nine folios, the existence of which had been forgotten for more than a century. The history of these volumes, so far as it could then be traced, was that in 1806 they had been received by a bookseller in Bern from an antiquary in Zurich who owed him four louis d'or which he was unable to pay; six years later, the Bern dealer sold the nine folios for a single louis d'or to a botanist, through whom they came into the possession of the Institute. Since the collection was obviously a remarkable one, and appeared to be of early date, Dr. Rytz examined it minutely. His researches and their results make a fascinating story, which is now set out in fully illustrated form*.

Of the nine folios, the herbarium occupies eight, while the ninth contains illustrations alone. The herbarium is far from complete; there is reason for believing that about ten more volumes may await some future happy discovery. Even in its incomplete form the collection contains 813 species drawn from a wide geographical area-Switzerland, Italy, France, Spain and Egypt. It also indicates activity of an adventurous kind, for there are specimens from Pilatus, Monte Baldo and the mountains of Savoy-peaks arousing little emotion among the alpinists of to-day, but most formidable in the eyes of the men of earlier centuries.

* Das Herharium Felix Platters. Ein Beitrag zur Geschichte der Botanik des XVI. Jahrhunderts. By Prof. Walther Rytz. (Verhandl. Naturforsch. Gesellsch. Basel, 44, pt. 1), 222 pp., 22 figures. (Basel: Naturforsch. Gesellsch., 1933.) 5 Sw. fr.

Pflanzenaquerelle des Hans Weiditz aus dem Jahre 1529: die Originale zu den Holzschnitten im Brunfels'schen Kräuterhuch. By Prof. Walther Rytz. 44 pp., 15 coloured plates. (Bern: By Prof. Walther Rytz. 60 Sw. fr.
The dried plants are well preserved and arranged, and some of them have retained their colour admirably; this point must have been regarded as of special importance, for, in some species of Campanula, the difficulty that the corollas turn brown on drying has been met by replacing them by imitations cut out of larkspur flowers! There are numerous inscriptions on the sheets, and all the information which could be gleaned from these has been brought together and analysed by Dr. Rytz, who has also made an exhaustive study of the paper used for mounting-a study which reveals no less than forty more or less different watermarks. All this research leads directly to the conclusion that the collection was formed in the second half of the sixteenth century by a botanist who was in relation with Charles de l'Écluse (1525-1609), Conrad Gesner (1516-65) and Joachim Camerarius (1534-98), from all three of whom he received specimens. After a process of delicate detective work, too complex and detailed to be summarised here, Dr. Rytz has decided that the herbarium was undoubtedly the work of Felix Platter, an eminent physician of Basle, who lived from 1536 until 1614. Fortunately, the facts of his life have been fully recorded and a fine contemporary portrait was available for reproduction in Dr. Rytz's first memoir.

From 1552 until 1557, Platter is known to have studied medicine at Montpellier, like so many botanists of his day, for example, Conrad Gesner, Jaques Dalechamps, Charles de l'Écluse, Jean Bauhin, Pierre Pena and Jean de l'Obel. In his diary of 1554, Platter speaks of collecting "viler kreuter, die ich in papier zierlich inmacht", so it is clear that he had already begun a herbarium 